\title{
Recent advances in the epidemiology and prevention of
}

\section{Streptococcus pneumoniae infections [version 1; peer review: 2}

\section{approved]}

\author{
Charles Feldman (1D) 1*, Ronald Anderson 2* \\ ${ }^{1}$ Department of Internal Medicine, Faculty of Health Sciences, University of the Witwatersrand, 7 York Road, Parktown, \\ Johannesburg, 2193, South Africa \\ ${ }^{2}$ Institute of Cellular and Molecular Medicine, Department of Immunology, Faculty of Health Sciences, University of Pretoria, 5 \\ Bophelo Road, Gezina, 0186, South Africa \\ * Equal contributors
}

\author{
V1 First published: 07 May 2020, 9(F1000 Faculty Rev):338 \\ https://doi.org/10.12688/f1000research.22341.1 \\ Latest published: 07 May 2020, 9(F1000 Faculty Rev):338 \\ https://doi.org/10.12688/f1000research.22341.1
}

\begin{abstract}
The introduction of pneumococcal conjugate vaccines (PCVs) 7 and 13 into national childhood immunization programs in the US in 2000 and 2010, respectively, proved to be remarkably successful in reducing infant mortality due to invasive pneumococcal disease (IPD), resulting in widespread uptake of these vaccines. Secondary herd protection of non-vaccinated adults against IPD has proven to be an additional public health benefit of childhood immunization with PCVs, particularly in the case of the vulnerable elderly who are at increased risk due to immunosenescence and underlying comorbidity. Despite these advances in pneumococcal immunization, the global burden of pneumococcal disease, albeit of unequal geographic distribution, remains high. Reasons for this include restricted access of children living in many developing countries to PCVs, the emergence of infection due to non-vaccine serotypes of the pneumococcus, and non-encapsulated strains of the pathogen. Emerging concerns affecting the elderly include the realization that herd protection conferred by the current generation of PCVs (PCV7, PCV10, and PCV13) has reached a ceiling in many countries at a time of global population aging, compounded by uncertainty surrounding those immunization strategies that induce optimum immunogenicity and protection against IPD in the elderly. All of the aforementioned issues, together with a consideration of pipeline and pending strategies to improve access to, and serotype coverage of, PCVs, are the focus areas of this review.
\end{abstract}

Open Peer Review

Approval Status

1 2

version 1

07 May 2020

Faculty Reviews are review articles written by the prestigious Members of Faculty Opinions. The articles are commissioned and peer reviewed before publication to ensure that the final, published version is comprehensive and accessible. The reviewers who approved the final version are listed with their names and affiliations.

1. Cheng-Hsun Chiu, Chang Gung Memorial Hospital, Chang Gung University College of Medicine, Taoyuan, Taiwan

2. Carlos Luna, Hospital de Clínicas, Universidad de Buenos Aires, Buenos Aires, Argentina

Any comments on the article can be found at the end of the article. 


\section{Keywords}

herd protection, invasive pneumococcal disease, pneumococcus, pneumococcal conjugate vaccine, prime-boost immunization, pneumococcal polysaccharide vaccine 23 , serotype replacement, Streptococcus pneumoniae

Corresponding author: Charles Feldman (charles.feldman@wits.ac.za)

Author roles: Feldman C: Conceptualization, Data Curation, Writing - Original Draft Preparation, Writing - Review \& Editing; Anderson R: Conceptualization, Data Curation, Writing - Original Draft Preparation, Writing - Review \& Editing

Competing interests: CF has acted on the advisory board and speakers bureau for Pfizer. RA declares that he has no competing interests.

Grant information: The author(s) declared that no grants were involved in supporting this work.

Copyright: $\odot 2020$ Feldman C and Anderson R. This is an open access article distributed under the terms of the Creative Commons Attribution License, which permits unrestricted use, distribution, and reproduction in any medium, provided the original work is properly cited.

How to cite this article: Feldman C and Anderson R. Recent advances in the epidemiology and prevention of Streptococcus pneumoniae infections [version 1; peer review: 2 approved] F1000Research 2020, 9(F1000 Faculty Rev):338

https://doi.org/10.12688/f1000research.22341.1

First published: 07 May 2020, 9(F1000 Faculty Rev):338 https://doi.org/10.12688/f1000research.22341.1 


\section{Introduction}

Worldwide, lower respiratory tract infections (LRTIs) are a major cause of morbidity and mortality. A systematic analysis of the Global Burden of Disease Study 2016 documented that LRTIs, encompassing pneumonia and bronchiolitis, accounted for 2,377,697 deaths (95\% uncertainty interval [UI] 2,145,584$2,512,809$ ) overall in 2016, encompassing 652,572 deaths $(586,475-720,612)$ in children younger than 5, and, more strikingly, 1,080,958 $(943,749-1,170,638)$ in adults older than $70^{1}$. Globally, Streptococcus pneumoniae (pneumococcus) was the leading cause of both morbidity and mortality among the LRTIs, contributing more deaths than all of the other studied etiologies combined (Haemophilus influenzae type b, influenza, and respiratory syncytial virus), and 1,189,937 deaths (95\% UI $690,445-1,770,660)$ were attributed to the pneumococcus. The authors concluded that, although progress had been made in addressing the burden of LRTIs, it has not been equal across all locations and that more effort needed to be focused on the elderly since almost three quarters of LRTI deaths occurred in older children and adults, and the mortality rate is particularly high in those older than 70. Furthermore, the authors indicated that risk factors, including comorbidities, which put the elderly at risk of LRTIs, needed to be explored further. Moreover, the impact of the introduction of the pneumococcal conjugate vaccine (PCV) on the elderly in low- and middle-income countries in particular needed to be evaluated.

This review explores recent data regarding the global burden of $S$. pneumoniae, the changing recommendations for, and effects of, the introduction of PCV, particularly in childhood immunization programs but also in adults, and describes what is new on the horizon for future pneumococcal vaccination.

\section{Burden of pneumococcal disease}

There appears to be a changing burden of pneumococcal infection, at least in certain parts of the world, and such is the decline in the rate of pneumococcal infections that, in the US, this microorganism is now believed to account for less than 10 to $15 \%$ of cases of community-acquired pneumonia $(\mathrm{CAP})^{2}$. For example, in a 2015 active population-based surveillance of hospitalized CAP in adult patients in the US (EPIC Study), the most common pathogens were rhinovirus ( $9 \%$ of patients), influenza virus $(6 \%)$ and the pneumococcus, which constituted $5 \%$ of the documented cases ${ }^{3}$. In Europe, on the other hand, the proportion of cases due to the pneumococcus is higher than that reported for the US and has been attributed to differences in vaccine practices and the habit of smoking ${ }^{2}$. For example, in a recent structured literature review that documented a varying but high burden of pneumococcal CAP in different countries in Europe, the burden occurred particularly among the elderly with comorbidities, despite the use of the 23-valent pneumococcal polysaccharide vaccine (PPV23) ${ }^{4}$. The importance of comorbidities in the burden of pneumococcal infections has also been documented in the US, where rates of pneumococcal disease in at-risk and high-risk adults are much higher than in healthy adults ${ }^{5}$.

One of the reasons that discrepancies exist in the frequencies of the documented etiologies in CAP in the different studies may relate to the definition of the etiology ${ }^{6}$. Blood culture is often considered the "gold standard" of microbiological diagnosis in bacterial CAP but lacks sensitivity, and although commercially available urine antigen detection tests for the pneumococcus and Legionella pneumophila have better efficacy, they still have a sensitivity of only about 70 to $80 \%{ }^{6}$. Recent advances have been made in the molecular methods for the detection of putative pathogens; however, it has been said that these novel diagnostic methods are challenging in the absence of a true gold standard and that studies using strict case definitions, radiographic review, and application of these tests to control specimens may help elucidate their validity ${ }^{6}$.

A recent study that evaluated the prevalence of pneumococcal pneumonia in patients hospitalized with CAP in Thailand used quantitative polymerase chain reaction of upper respiratory tract secretions and a commercially available urine antigen test (UAT) (BinaxNOW) together with Bayesian latent class modelling and conventional (BLCM) analysis?. The BLCM analysis suggested a greater than $25 \%$ higher prevalence of pneumococcal pneumonia than that estimated by a conventional approach when assuming UAT to be the gold-standard reference test. In the EPIC Study, most of the pneumococcal infections were documented by using the BinaxNOW ${ }^{3}$. However, when a novel serotype-specific urine antigen detection assay was applied to residual stored urine specimens from this study, it substantially increased the documentation of pneumococcal infection among the CAP cases, even though it diagnosed only serotypes contained in $\mathrm{PCV}_{13}{ }^{8}$. Another prospective observational surveillance study of hospitalized CAP cases across 10 geographically dispersed cities in the US used cultures of the respiratory tract and normally sterile sites as well as the same serotype-specific urine antigen detection assay, and the authors concluded that, despite the uptake of PCV programs in children and associated herd protection in adults, there remained a persistent burden of PCV13-type CAP in the US 9

Other studies and reviews published in the last four years from different parts of the world, including Australia ${ }^{10,11}$ and the Asia Pacific region ${ }^{12}$, Canada ${ }^{13,14}$, Latin America ${ }^{15-17}$, and the Caribbean ${ }^{17}$, have documented similar findings. Namely, there is an ongoing high rate of pneumococcal pneumonia in all of these regions; in more recent years, this is often the case despite decreased rates associated with herd protection in adults from implementation of childhood PCV immunization as well as a residual burden of vaccine-serotype pneumonia and invasive pneumococcal disease (IPD), as described above.

\section{Pneumococcal vaccination}

A number of recent reviews of pneumococcal vaccination have described the differences between PPV23, the 23-valent polysaccharide vaccine, and PCV13, the 13-valent pneumococcal polysaccharide conjugate vaccine, the two vaccines that are registered for use in adults. These reviews recognize (i) the ability of the conjugate vaccine to inhibit carriage of vaccine serotypes in vaccinated children, resulting in not only direct protection but also indirect herd protection among unvaccinated children and adults $^{18}$, (ii) the importance of nasopharyngeal carriage and an 
understanding of the immunological mechanisms that confer protection against colonization and facilitate novel vaccine development and evaluation ${ }^{19}$, and (iii) the need to study memory B-cell responses more intensively to fully understand long-term protection with $\mathrm{PCV}^{20}$.

\section{Herd protection}

Introduction of the various conjugate vaccines into routine childhood vaccination programs, including PCV7 ${ }^{21,22}, \mathrm{PCV} 10^{23,24}$, and PCV13 ${ }^{25-27}$, was shown to result in a decrease in serotype-specific IPD or pneumococcal pneumonia or both in the vaccinated individuals and adults, particularly the elderly, the latter via indirect herd protection. These include studies of $\mathrm{PCV}^{22}$ and PCV10 ${ }^{24}$ in low- and middle-income countries. Clearly, however, the results of additional studies from developing countries, several of which are ongoing, are necessary to accurately determine whether the impact of introduction of PCV is comparable to that in the developed world ${ }^{28}$. The indirect effects of PCV on IPD or pneumococcal pneumonia (or both) in older adults appear to be dependent on PCV coverage rates, time from PCV implementation and differed according to the specific PCV used $^{29,30}$.

\section{Serotype replacement disease}

It is clear from a myriad of recent single-country studies (Ireland ${ }^{31}$, England and Wales ${ }^{32}$, Japan ${ }^{33}$, Canada ${ }^{34,35}$, and Portugal ${ }^{36}$ ) and from surveys and systematic reviews/meta-analyses ${ }^{37,38}$ that, with the progressive introduction of PCV in childhood immunization programs and the associated direct and indirect benefits of reducing vaccine serotype disease, serotype replacement disease/ infection has also occurred in both children and adults, in some cases mainly in adults and especially in older adults. This has resulted from an increase in serotypes that are not covered by the specific vaccine introduced (for example, increase in unique PCV13 serotypes with introduction of PCV7 or increase in unique PPV23 serotypes, and non-vaccine serotypes [NVTs], after introduction of PCV13). Clearly, there are geographical differences in serotype replacement and there is a striking difference between the UK and the US ${ }^{39}$. In the UK, as in Europe, NVT IPD has occurred mainly in older adults, whereas in the US NVT IPD has remained relatively stable in young children and older people. The authors contend that it is difficult to fully understand the reason (or reasons) for these differences since the circumstances in the two countries are otherwise very similar.

In some countries, such as Canada ${ }^{35}$ and Portugal ${ }^{36}$ and others ${ }^{40}$, there has also been an increase in serotype 3 pneumococcal infection despite the introduction of PCV13, which contains serotype 3 , and there is a lower efficacy of PCV13 in combatting serotype 3 as compared with other serotypes ${ }^{40}$. These factors have led some of these authors to suggest that changes in vaccination strategies in adults need to be considered in order to build on the successes of PCVs in children, which are potentially being undermined by serotype replacement $t^{31,34,37}$.

\section{Recommendations for vaccination in adults, including the elderly}

Currently, two vaccines are registered for use in adults, namely PPV23 and PCV13 ${ }^{41,42}$. Recommendations have been made for their use on the basis of age and risk factors in adults, although changes in the exact recommendations and the dosing intervals have been made over the years, as reviewed elsewhere ${ }^{41-43}$. However, new changes in the recommendations were recently published by the Centers for Disease Control and Prevention (CDC) (US $)^{44}$. This relates primarily to the use of both PCV13 and PPV23 in adults who are at least 65 years old.

The earlier recommendation by the CDC for the dual use of these two vaccines in adults who are at least 65 years old ${ }^{45}$ was made in 2014 in recognition of the following: (i) despite herd protection in adults, there remained a residual burden of PCV13 serotype pneumococcal infection in adults; (ii) an increase in unique PPV23 serotype infection due to serotype replacement disease in adults; (iii) the importance of the burden of nonbacteremic pneumococcal pneumonia and new evidence from the Community-Acquired Pneumonia Immunization Trial in Adults (CAPiTA) that PCV13 was effective against non-bacteremic infections ${ }^{46}$; (iv) data that suggested that although PPV23 was efficacious in preventing IPD among healthy young adults and generally healthy older individuals, studies of its efficacy in nonbacteremic infections were contradictory; and (v) acquisition of immunogenicity data supporting the use of PCV13 followed by PPV23 data ("prime boost" phenomenon), even in immunocompromised individuals ${ }^{46-49}$.

In the case of pneumococcal immunization, the recommended "prime boost" immunization strategy involves initial immunization with a single dose of PCV13 followed weeks or months later by a single dose of PPV23 in vaccine-naïve individuals. The perceived advantages of this strategy, investigated originally in vaccine-naïve elderly persons ${ }^{48}$, are cost-effectiveness, maximizing the number of vaccine serotypes and augmentation of immunogenicity. Sadlier et al. have also demonstrated the efficacy of the PCV13/PPV23 "prime boost" immunization strategy in HIV-infected persons ${ }^{47}$. In that study, HIV-infected persons $(n=64)$ were stratified to receive PCV13 followed 4 weeks later by PPV23 $(n=31$ persons) or PPV23 at week 4 only $(n=33$ persons). Measurement of serotype-specific $\operatorname{IgG}$ antibodies and functional opsonophagocytic antibodies was performed 8 and 28 weeks after administration of PPV $23^{47}$. The authors reported that the "prime boost" group was more likely to achieve increases of between two- and four-fold in the serum concentrations of serotype-specific and opsonophagocytic antibodies, respectively, at both time intervals tested ${ }^{47}$.

Despite the apparent potential of the pneumococcal "prime boost" immunization strategy, several important concerns remain. These include (i) identifying the optimum interval between administration of PCV13 and PPV23, (ii) the duration of immunological protection, (iii) induction of immune hyporesponsiveness due to subsequent "boosting" with PPV23, (iv) failure of this strategy to induce persistent augmentation of protective antibody responses in clinical settings other than HIV infection ${ }^{50}$, and (v) absence of compelling clinical trial data demonstrating efficacy in the prevention of severe pneumococcal infection.

Two opinion pieces were subsequently published in JAMA Internal Medicine by experts debating these recommendations, 
either supporting these recommendations or citing a potential lack of evidence for this recommendation, the complexity of the recommendations, and associated increased costs ${ }^{51,52}$. Nevertheless, it was recognized at that time that these recommendations would need to be re-looked at in the future as herd protection increased. This was done in 2019, when the recommendations of the CDC were again changed; the indication was that all adults at least 65 years of age should continue to receive PPV23 but that there should be shared decision making regarding preceding use of PCV13 in this age group among patients who do not have an immune-compromising condition, cerebrospinal fluid leak, cochlear implant, or increased risk of exposure to PCV 13 serotypes ${ }^{44}$.

\section{Ongoing controversies in adult pneumococcal vaccination}

Nevertheless, there is still considerable debate about the best way to protect adults, including the elderly, against pneumococcal infection, and many questions need to be answered. There is also recognition that there are differences in different geographical regions with regard to both the residual burden of PCV-serotype disease following childhood vaccination and the extent of serotype replacement disease in both adults and children $^{53}$. As indicated previously, it is not completely clear why Europe and the US differ in both of these regards ${ }^{53,54}$. Furthermore, there needs to be a consideration of whether the herd protection of adults through childhood vaccination is as good a way of protecting adults as actively immunizing them ${ }^{54,55}$. It has even been suggested that some countries appear to have reached the limits of their herd protection ${ }^{56}$, and a study from Switzerland even showed an increase in all-cause pneumonia and pneumococcal pneumonia in adults following introduction of pneumococcal vaccination in children ${ }^{57}$.

There are additional issues that need to be addressed in the overall consideration of both PCV13 and PPV23 vaccination in adults. In this context, the ongoing incidence of PCV-serotype infections, particularly non-bacteremic infections, may be underestimated. For example, one study from Spain in immunocompetent adults hospitalized with CAP noted that infections with serotypes included in PCV13 still occurred commonly in both healthy individuals and those with underlying conditions, following introduction of PCV13, when this was diagnosed by using the serotype-specific UAT $^{58}$. Another study from Spain confirmed the value of the commercially available UAT to increase the detection rate of pneumococcal infections ${ }^{59}$. In addition, while some have questioned the use of PPV23 in adults, largely because of possible hyporesponsiveness occurring after its use ${ }^{60}$, this needs to be counterbalanced by recent studies indicating a potential benefit of PPV23 against both IPD and non-bacteremic pneumococcal infections ${ }^{61-63}$. Clearly, many factors influence the incidence of pneumococcal disease and the response to pneumococcal vaccination, including personal conditions, geographical and ethnic factors, and social risks, not all of which have been considered ${ }^{64}$. Certainly, many countries have an aging population, and adults, both young and older with underlying medical conditions, have an increased risk of pneumococcal pneumonia and $\operatorname{IPD}^{57,65,66}$, and although declines in pneumococcal disease have occurred in older adults and in those with comorbidities following the introduction of childhood PCV13 immunization, these declines have been attenuated ${ }^{66}$. So the holy grail is, what is the future of adult pneumococcal vaccination ${ }^{67}$ ?

\section{New-generation pneumococcal conjugate vaccines}

Important concerns driving the development of new-generation PCVs include the following:

- An increasing realization (as covered in detail above) that the extent of herd protection provided by existing vaccine coverage (PCV7/PCV13) appears to have plateaued in many geographic regions ${ }^{56}$. This limitation of existing vaccines necessitates the development of novel extended-coverage PCVs to counter the threat posed by NVTs and also to potentiate the immunogenicity of the PCV13 serotypes 4, 19F, and 19A and serotype 3 in particular ${ }^{56,68}$. Although these novel vaccines will contribute to the efficacy of pneumococcal immunization programs in children, they are expected to offer considerable benefit to the elderly and other groups at high risk for the development of pneumonia and IPD. PCV15 and PCV20 are new-generation vaccines that fall into this category; the major beneficiaries of advances in pneumococcal immunization strategies have been children living in high-income countries where PCV7, PCV10, and PCV13 have been enthusiastically and effectively included in national childhood immunization programs. In many instances, children living in low-income countries have experienced similar benefit, largely through the efforts of the "Global Alliance for Vaccines and Immunization", now known as "Gavi, the Vaccine Alliance". This is an international philanthropic organization that, through negotiation and sponsorship, has enabled access to vaccines, including PCVs, for children living in some of the world's poorest countries. However, in spite of these efforts, it has been estimated that 500,000 pneumococcal deaths occurred in children between 1 and 59 months of age in $2015^{69,70}$. Most of these deaths occurred in developing countries, and India, Nigeria, the Democratic Republic of Congo, and Pakistan accounted for $50 \%$ of these $\mathrm{e}^{69,70}$. Mercifully, a more affordable new PCV10 targeting serotypes (1, 5 , 6A, 6B, $7 \mathrm{~F}, 9 \mathrm{~V}, 14,19 \mathrm{~A}, 19 \mathrm{~F}$, and $23 \mathrm{~F}$ ) of the pathogen, which are common in African and Asian countries, has been granted prequalification status ("facilitated access to medicines that meet the unified standards of quality, safety and efficacy") by the World Health Organization $^{71}$. The vaccine, known as Pneumosil ${ }^{\circledR}$, will be available to low- and middle-income countries.

PCV20

Of the two third-generation extended-coverage PCVs (PCV15 and PCV20), the latter is in the most advanced stages of clinical evaluation (safety and immunogenicity). The vaccine was designed primarily for immunization of adults. In addition to the capsular polysaccharides present in PCV13, which are 
derived from serotypes $1,3,4,5,6 \mathrm{~A}, 6 \mathrm{~B}, 7 \mathrm{~F}, 9 \mathrm{~V}, 14,18 \mathrm{C}, 19 \mathrm{~A}$, $19 \mathrm{~F}$, and $23 \mathrm{~F}$, the seven new serotypes contained in PCV20 are $8,10 \mathrm{~A}, 11 \mathrm{~A}, 12 \mathrm{~F}, 15 \mathrm{~B} / \mathrm{C}, 22 \mathrm{~F}$, and $33 \mathrm{~F}^{72}$. Inclusion of the new serotypes confers additional protection against fatal disease $(8,10 \mathrm{~A}, 11 \mathrm{~A}, 15 \mathrm{~B} / \mathrm{C}, 22 \mathrm{~F}$, and $33 \mathrm{~F})$, infection with antibioticresistant strains of the pathogen $(11 \mathrm{~A}, 15 \mathrm{~B} / \mathrm{C}, 22 \mathrm{~F}$, and $33 \mathrm{~F})$, and meningitis $(10 \mathrm{~A}, 15 \mathrm{~B} / \mathrm{C}, 22 \mathrm{~F} \text {, and } 33 \mathrm{~F})^{72}$. PCV20 has successfully completed phase 1 and phase 2 clinical evaluations. The phase 1 trial (randomized, controlled observer-blind, two-arm parallel design) assessed the safety, tolerability, and immunogenicity in healthy, immunocompetent adult humans $(\mathrm{n}=66)$ (age of 18 to 49 years) with no history of pneumococcal immunization ${ }^{73}$. Participants were randomly assigned to receive a single intramuscular dose of PCV20 alone $(n=33)$ or a licensed combination of tetanus, diphtheria, cellular pertussis vaccine. Immunogenicity (opsonophagocytic antibody titers and concentrations of capsular-specific IgG antibodies) was measured 4 weeks post-immunization and the overall safety profile over 6 months $^{73}$. Impressive immunogenicity and safety were evident on completion of this trial.

The phase 2 trial included 444 vaccine-naïve, immunocompetent adults (age of 60 to 64 years) randomly assigned to receive either PCV13 or PCV20 (single intramuscular injection) followed by assessment of immunogenicity and safety ${ }^{74}$. No safety concerns were evident, while immunogenicity was impressive and significant increases in opsonophagocytic antibody titers were detected for all capsular polysaccharides present in PCV20. Geometric mean fold increases from baseline of 6.1 to 68.6 and 9.0 to 112.2 were detected for antibodies targeting capsular polysaccharides present in PCV 13 only and for the additional capsular polysaccharides in PCV20, respectively ${ }^{74}$. On the basis of these findings, the US Food and Drug Administration awarded "breakthrough therapy status" to PCV20 (expedited evaluation and development).

Subsequently, the Pfizer Vaccine R\&D Program has initiated three phase 3 clinical trials, all scheduled for completion in early 2020. Notwithstanding safety issues, the primary phase 3 trial (ClinicalTrials.gov Identifier: NCT03760146) ${ }^{72}$, to which 3880 healthy, vaccine-naïve adults have been recruited, is focused on (i) a comparison of the immune responses to PCV20 and dual PCV13/PPV23 immunization in subjects at least 60 years old and (ii) the immunogenicity of PCV20 in persons 18 to 59 years old ${ }^{72}$.

The second phase 3 trial (ClinicalTrials.gov Identifier: NCT03835975 $)^{72}$ is focused on the evaluation of safety and immunogenicity of PCV20 in elderly adults $(n=785$, at least 65 years old) who had received prior immunization with PCV13 alone ( $\geq 6$ months earlier) or with PPV23 alone ( $\geq 1$ year to $<5$ years earlier) or PCV13 followed by PPV23 ( $\geq 1$ year earlier) ${ }^{72}$.

In addition to providing additional safety data, the third phase 3 trial (ClinicalTrials.gov Identifier: NCT03828617) ${ }^{72}$, to which 1610 adults (age of 18 to 49 years) with no history of pneumococcal immunization have been enrolled, is designed to evaluate the immunogenicity of three different lots of PCV20.

Considering estimates that about 79,000 of the 1.1 million cases of adults hospitalized with CAP in the US annually are caused by serotypes of the pneumococcus represented in PCV20, Thompson et al. recently proposed that a significant number of these cases may be prevented by immunization with this vaccine $^{73}$.

\section{PCV15}

The second third-generation PCV, PCV15, produced by Merck Vaccines, consists of the 13 pneumococcal serotypes present in PCV13 (1, 3, 4, 5, 6A, 6B, 7F, 9V, 14, 18C, 19A, 19F, and 23F) together with the additional serotypes $22 \mathrm{~F}$ and $33 \mathrm{~F}^{75}$, which (as mentioned above) are associated with infection caused by antibiotic-resistant strains of the pneumococcus as well as with severe disease, including meningitis. Unlike PCV20, which appears to target the prevention of severe pneumococcal disease in adults, PCV15 will be used in both the pediatric and adult settings. The safety and efficacy of PCV15 have been demonstrated in several phase 2 clinical trials undertaken in children ${ }^{75}$ and adults $^{76,77}$ and in a pre-clinical experimental animal study ${ }^{78}$.

In a pediatric setting, Greenberg et al. recently reported the results of a multicenter $(n=58)$, phase 2 clinical trial (ClinicalTrials.gov Identifier: NCT01215188) encompassing five countries (US, Canada, Finland, Israel, and Spain) and 1148 healthy infants $^{75}$. Relative to the comparator vaccine (PCV13), PCV15 had an acceptable safety profile, and immunogenicity (four doses of vaccine administered at $2,4,6,8$, and 12 to 15 months of age) was also comparable to that of PCV13.

Two phase 2 trials undertaken by the same group investigated the safety and immunogenicity of PCV15 relative to those of PCV13 in adults ${ }^{76}$. The first of these (ClinicalTrials.gov Identifier: NCT02547649), to which healthy adults $(n=690)$ younger than 50 years were enrolled, compared the safety and immunogenicity of PCV15 with those of PCV13, which were found to be comparable ${ }^{76}$. The second study, to which adults (age of at least 65 years) who had previously been immunized with PPV23 were enrolled $(n=253)$, compared the safety and immunogenicity of PCV15 with those of PCV13 ${ }^{77}$. The authors reported that PCV15 was "generally well tolerated and induced high levels of $\mathrm{IgG}$ and opsonophagocytic antibodies to all 15 serotypes included in the vaccine when given as a single dose to adults at least 65 years of age previously vaccinated with PPV23" $" 77$.

The authors of the aforementioned studies contend that PCV15 will provide necessary additional protection against the threat of IPD posed by serotypes $22 \mathrm{~F}$ and $33 \mathrm{~F}$, which has emerged following the introduction of PCV13.

\section{Serotype-independent pneumococcal vaccines}

Despite the remarkable public health impact of PCVs in infant immunization, ongoing challenges persist, specifically those presented by serotype replacement with NVTs of the pneumococcus as well as the emergence of non-encapsulated strains of the pathogen. In the opinion of many experts, the development of vaccines based on highly conserved and immunogenic protein antigens remains the "holy grail" of universal pneumococcal immunization ${ }^{79}$. Potential immunization strategies of this type include (i) vaccines based on single recombinant 
pneumococcal proteins or combinations of these, (ii) combining recombinant protein antigens with PCVs, and (iii) attenuated, non-encapsulated whole-cell vaccines, in which immunogenic surface proteins of the pathogen are exposed ${ }^{80}$. An example of the latter type of vaccine is that derived from a non-proliferating and non-encapsulated strain of the pneumococcus (RM200 RXIE Pdt $\Delta$ lytA) in which the lytA (autolysin) and ply genes are deleted and inactivated, respectively ${ }^{81}$.

However, to the best of our knowledge, no vaccine of any of the aforementioned types has progressed beyond the early stages of clinical evaluation. Two PCV/recombinant protein vaccines have reached phase 2 evaluation. These are (i) a vaccine based on PCV13 in combination with two recombinant pneumococcal proteins (pneumolysin toxoid and pneumococcal histidine triad protein $\mathrm{D}^{82}$ ) and (ii) a variant of PCV10, known as PhiD-CV (which consists of serotypes 1, 4, 5, 6B, 7F, 9V, 14, $18 \mathrm{C}, 19 \mathrm{~F}$, and $23 \mathrm{~F}$ with eight capsular polysaccharides conjugated to protein $\mathrm{D}$ of non-typeable $H$. influenzae and the others to tetanus or diphtheria toxoid), in combination with the same two pneumococcal proteins ${ }^{83}$.

\section{Conclusions}

The ongoing development and uptake of PCVs into national childhood immunization programs in many countries have impacted enormously on the public health threat posed by severe pneumococcal disease. Nevertheless, the burden of pneumococcal disease remains high in many countries, including those with compulsory childhood access to PCVs. Although a major contributing factor remains the limited serotype coverage provided by PCVs and the associated emergence of IPD caused by NVTs of the pneumococcus, other factors are also at play. These include recognition of disease caused by non-encapsulated strains of the pathogen, reaching the ceiling of herd protection, and the uncertainty surrounding the efficacy of current immunization practices in high-risk groups, compounded by global population aging and associated immunosenescence and comorbidity. Although expanded serotype coverage vaccines have been targeted for expedited approval, issues such as affordability and vaccine efficacy in the face of ongoing serotype replacement are likely to remain significant concerns. The search continues for a serotype-independent vaccine to counter the global burden of pneumococcal disease.
1. Troeger C, Blacker B, Khalil IA, et al.: Estimates of the global, regional, and national morbidity, mortality, and aetiologies of lower respiratory infections in 195 countries, 1990-2016: a systematic analysis for the Global Burden of Disease Study 2016. Lancet Infect Dis. 2018; 18(11): 1191-210. Disease Study 2016. Lancet Infect Dis. 2018; 18(11): 1191-
PubMed Abstract | Publisher Full Text | Free Full Text

2. Musher DM, Abers MS, Bartlett JG: Evolving Understanding of the Causes of Pneumonia in Adults, With Special Attention to the Role of Pneumococcus. Clin Infect Dis. 2017; 65(10): 1736-44. PubMed Abstract | Publisher Full Text | Free Full Text

3. F Jain S, Self WH, Wunderink RG, et al.: Community-Acquired Pneumonia Requiring Hospitalization among U.S. Adults. N Engl J Med. 2015; 373(5): $415-27$.

PubMed Abstract | Publisher Full Text | Free Full Text | F1000 Recommendation

4. Torres A, Cillóniz C, Blasi F, et al.: Burden of pneumococcal communityacquired pneumonia in adults across Europe: A literature review. Respir Med. 2018; 137: 6-13.

PubMed Abstract | Publisher Full Text

5. Zhang D, Petigara T, Yang X: Clinical and economic burden of pneumococcal disease in US adults aged 19-64 years with chronic or immunocompromising diseases: an observational database study. BMC Infect Dis. 2018; 18(1): 436. PubMed Abstract | Publisher Full Text | Free Full Text

6. Jain S, Pavia AT: Editorial Commentary: The Modern Quest for the "Holy Grail" of Pneumonia Etiology. Clin Infect Dis. 2016; 62(7): 826-8. PubMed Abstract | Publisher Full Text

7. $\mathrm{F} L u Y$, Joseph L, Bélisle $P$, et al:: Pneumococcal pneumonia prevalence among adults with severe acute respiratory illness in Thailand - comparison of Bayesian latent class modeling and conventional analysis. BMC Infect Dis. 2019; 19(1): 423

PubMed Abstract | Publisher Full Text | Free Full Text | F1000 Recommendation

8. Wunderink RG, Self WH, Anderson EJ, et al:: Pneumococcal CommunityAcquired Pneumonia Detected by Serotype-Specific Urinary Antigen Detection Assays. Clin Infect Dis. 2018; 66(10): 1504-10. PubMed Abstract | Publisher Full Text | Free Full Text

9. F Isturiz RE, Ramirez J, Self WH, et al:: Pneumococcal epidemiology among us adults hospitalized for community-acquired pneumonia. Vaccine. 2019; 37(25): 3352-61.

PubMed Abstract | Publisher Full Text | F1000 Recommendation

10. Earle K, Williams S: Burden of pneumococcal disease in adults aged 65 years and older: an Australian perspective. Pneumonia (Nathan). 2016; 8: 9. PubMed Abstract | Publisher Full Text | Free Full Text
11. Yin JK, Jayasinghe SH, Charles PG, et al:: Determining the contribution of Streptococcus pneumoniae to community-acquired pneumonia in Australia. Med J Aust. 2017; 207(9): 396-400. Publisher Full Text

12. Song JH, Huh K, Chung DR: Community-Acquired Pneumonia in the AsiaPacific Region. Semin Respir Crit Care Med. 2016; 37(6): 839-54. PubMed Abstract | Publisher Full Text | Free Full Text

13. McNeil SA, Qizilbash N, Ye J, et al.: A Retrospective Study of the Clinical Burden of Hospitalized All-Cause and Pneumococcal Pneumonia in Canada. Can Respir J. 2016; 2016: 3605834. PubMed Abstract | Publisher Full Text | Free Full Text

14. LeBlanc JJ, EISherif M, Ye L, et al.: Burden of vaccine-preventable pneumococcal disease in hospitalized adults: A Canadian Immunization Research Network (CIRN) Serious Outcomes Surveillance (SOS) network study. Vaccine. 2017; 35(29): 3647-54. PubMed Abstract | Publisher Full Text

15. Iannella $\mathrm{H}$, Luna $\mathrm{CM}$ : Community-acquired pneumonia in Latin America. Semin Respir Crit Care Med. 2016; 37(6): 868-75. PubMed Abstract | Publisher Full Text

16. Michelin L, Weber FM, Scolari BW, et al.: Mortality and costs of pneumococcal pneumonia in adults: a cross-sectional study. J Bras Pneumol. 2019; 45(6): e20180374.

PubMed Abstract | Publisher Full Text

17. De la Hoz Restrepo F, Loo JD, Carvalho AF, et al.: The burden of pneumococcal disease in older children and adults in Latin America and the Caribbean. Sabin Vaccine Institute, 2018. Reference Source

18. Jochems SP, Weiser JN, Malley R, et al:: The immunological mechanisms that control pneumococcal carriage. PLOS Pathog. 2017; 13(12): e1006665. PubMed Abstract | Publisher Full Text | Free Full Text

19. Croucher NJ, Løchen A, Bentley SD: Pneumococcal Vaccines: Host Interactions, Population Dynamics, and Design Principles. Annu Rev Microbiol. 2018; 72: 521-49.

PubMed Abstract | Publisher Full Text

20. F Papadatou I, Tzovara I, Licciardi PV: The Role of Serotype-Specific Immunological Memory in Pneumococcal Vaccination: Current Knowledge and Future Prospects. Vaccines (Basel). 2019; 7(1): pii: E13. PubMed Abstract | Publisher Full Text | Free Full Text | F1000 Recommendation

21. Myint TT, Madhava H, Balmer P, et al.: The impact of 7-valent pneumococcal conjugate vaccine on invasive pneumococcal disease: a literature review. 
Adv Ther. 2013; 30(2): 127-51

PubMed Abstract | Publisher Full Text

22. von Gottberg A, de Gouveia L, Tempia S, et al: Effects of vaccination on invasive pneumococcal disease in South Africa. N Engl J Med. 2014; 371(20): 1889-99. PubMed Abstract | Publisher Full Text

23. Quirk SJ, Haraldsson G, Hjálmarsdóttir MÁ, et al.: Vaccination of Icelandic Children with the 10-Valent Pneumococcal Vaccine Leads to a Significant Herd Effect among Adults in Iceland. J Clin Microbiol. 2019; 57(4): pii: e01766-18. PubMed Abstract | Publisher Full Text | Free Full Text

24. Hammitt LL, Etyang AO, Morpeth SC, et al.: Effect of ten-valent pneumococcal conjugate vaccine on invasive pneumococcal disease and nasopharyngeal carriage in Kenya: a longitudinal surveillance study. Lancet. 2019; 393(10186): 2146-54.

PubMed Abstract | Publisher Full Text | Free Full Text

25. Rodrigo C, Bewick T, Sheppard C, et al:: Impact of infant 13-valent pneumococcal conjugate vaccine on serotypes in adult pneumonia. Eur Respir J. 2015; 45(6): 1632-41.

PubMed Abstract | Publisher Full Tex

26. F Moore MR, Link-Gelles R, Schaffner W, et al.: Effect of use of 13-valent neumococcal conjugate vaccine in children on invasive pneumococcal disease in children and adults in the USA: analysis of multisite, populationbased surveillance. Lancet Infect Dis. 2015; 15(3): 301-9.

PubMed Abstract | Publisher Full Text | Free Full Text | F1000 Recommendation

27. Sando E, Suzuki M, Furumoto A, et al.: Impact of the pediatric 13-valent pneumococcal conjugate vaccine on serotype distribution and clinical characteristics of pneumococcal pneumonia in adults: The Japan Pneumococcal Vaccine Effectiveness Study (J-PAVE). Vaccine. 2019; 37(20): 2687-93.

PubMed Abstract | Publisher Full Text

28. F Murdoch DR: Assessing the Impact of Pneumococcal Conjugate Vaccines. Clin Infect Dis. 2020; 70(8): 1589-1590.

PubMed Abstract | Publisher Full Text | F1000 Recommendation

29. Tsaban G, Ben-Shimol S: Indirect (herd) protection, following pneumococcal conjugated vaccines introduction: A systematic review of the literature. Vaccine. 2017; 35(22): 2882-91.

PubMed Abstract | Publisher Full Text

30. Hanquet G, Krizova P, Valentiner-Branth $P$, et al:: Effect of childhood pneumococcal conjugate vaccination on invasive disease in older adults of 10 European countries: implications for adult vaccination. Thorax. 2019; 74(5): 473-82.

PubMed Abstract | Publisher Full Text | Free Full Text

31. Corcoran $\mathrm{M}$, Vickers I, Mereckiene J, et al.: The epidemiology of invasive pneumococcal disease in older adults in the post-PCV era. Has there been a herd effect? Epidemiol Infect. 2017; 145(11): 2390-9.

PubMed Abstract | Publisher Full Tex

32. Ladhani SN, Collins S, Djennad A, et al:: Rapid increase in non-vaccine serotypes causing invasive pneumococcal disease in England and Wales, 2000-17: a prospective national observational cohort study. Lancet Infect Dis 2018; 18(4): 441-51.

PubMed Abstract | Publisher Full Text

33. Katoh S, Suzuki M, Ariyoshi K, et al:: Serotype replacement in adult pneumococcal pneumonia after the introduction of seven-valent pneumococcal conjugate vaccines for children in Japan: a systematic literature review and pooled data analysis. Jpn J Infect Dis. 2017; 70(5): 495-501.

PubMed Abstract | Publisher Full Text

34. Desai S, Policarpio ME, Wong K, et al:: The epidemiology of invasive pneumococcal disease in older adults from 2007 to 2014 in Ontario, Canada: a population-based study. CMAJ Open. 2016; 4(3): E545-E550.

PubMed Abstract | Publisher Full Text | Free Full Text

35. Wijayasri S, Hillier K, Lim GH, et al.: The shifting epidemiology and serotype distribution of invasive pneumococcal disease in Ontario, Canada, 2007-2017. PLoS One. 2019; 14(12): e0226353.

PubMed Abstract | Publisher Full Text | Free Full Text

36. Horácio AN, Silva-Costa C, Lopes JP, et al:: Serotype 3 remains the leading cause of invasive pneumococcal disease in adults in Portugal (2012-2014) despite continued reductions in other 13-valent conjugate vaccine serotypes. Front Microbiol. 2016; 7: 1616.

PubMed Abstract | Publisher Full Text | Free Full Text

37. Izurieta $\mathrm{P}$, Bahety $\mathrm{P}$, Adegbola R, et al:: Public health impact of pneumococcal conjugate vaccine infant immunization programs: assessment of invasive pneumococcal disease burden and serotype distribution. Expert Rev Vaccines. 2018; 17(6): 479-93.

PubMed Abstract | Publisher Full Text

38. Vadlamudi NK, Chen A, Marra F: Impact of the 13-valent pneumococcal conjugate vaccine among adults: a systematic review and meta-analysis. Clin Infect Dis. 2019; 69(1): 34-49.

PubMed Abstract | Publisher Full Text

39. F Lewnard JA, Hanage WP: Making sense of differences in pneumococcal Fe replacement. Lancet Infect Dis. 2019; 19(6): e213-e220. PubMed Abstract | Publisher Full Text | F1000 Recommendation

40. F Linley E, Bell A, Gritzfeld JF, et al:: Should pneumococcal serotype $\mathbf{3}$ be included in serotype-specific immunoassays? Vaccines (Basel). 2019; 7(1): pii: E4

PubMed Abstract | Publisher Full Text | Free Full Text | F1000 Recommendation

41. Kobayashi M, Bennett NM, Gierke R, et al:: Intervals between PCV13 and PPSV23 vaccines: recommendations of the Advisory Committee on Immunization Practices (ACIP). MMWR Morb Mortal Wkly Rep. 2015; 64(34): 944-7. PubMed Abstract | Publisher Full Text

42. Berical AC, Harris D, Dela Cruz CS, et al:: Pneumococcal vaccination strategies. an update and perspective. Ann Am Thorac Soc. 2016; 13(6): 933-44. PubMed Abstract | Publisher Full Text | Free Full Text

43. Perez F, Jump RL: New developments in adult vaccination: Challenges and opportunities to protect vulnerable veterans from pneumococcal disease. Fed Pract. $2015 ; 32(12): 12-19$

Free Full Text

44. F Matanock A, Lee G, Gierke R, et al.: Use of 13-valent pneumococcal conjugate vaccine and 23-valent pneumococcal polysaccharide vaccine among adults aged $\geq 65$ years: updated recommendations of the Advisory Committee on Immunization Practices. MMWR Morb Mortal Wkly Rep. 2019; 68(46): 1069-75.

PubMed Abstract | Publisher Full Text | Free Full Text | F1000 Recommendation

45. Tomczyk S, Bennett NM, Stoecker C, et al.: Use of 13-valent pneumococca conjugate vaccine and 23-valent pneumococcal polysaccharide vaccine among adults aged $\geq 65$ years: recommendations of the Advisory Committee on Immunization Practices (ACIP). MMWR Morb Mortal Wkly Rep. 2014; 63(37) 822-5.

PubMed Abstract | Free Full Text

46. Pilishvili T, Bennett NM: Pneumococcal disease prevention among adults: strategies for the use of pneumococcal vaccines. Am J Prev Med. 2015 49(6 Suppl 4): S383-90.

PubMed Abstract | Publisher Full Text

47. Sadlier C, O'Dea S, Bennett K, et al.: Immunological efficacy of pneumococcal vaccine strategies in HIV-infected adults: a randomized clinical trial. Sci Rep. 2016; 6: 32076 .

PubMed Abstract | Publisher Full Text | Free Full Text

48. Greenberg RN, Gurtman A, Frenck RW, et al:: Sequential administration of 13-valent pneumococcal conjugate vaccine and 23-valent pneumococcal polysaccharide vaccine in pneumococcal vaccine-naïve adults $60-64$ years of age. Vaccine. 2014; 32(20): 2364-74.

PubMed Abstract | Publisher Full Tex

49. Jackson LA, Gurtman A, van Cleeff M, et al.: Immunogenicity and safety of a 13-valent pneumococcal conjugate vaccine compared to a 23-valent pneumococcal polysaccharide vaccine in pneumococcal vaccine-naive adults. Vaccine. 2013; 31(35): 3577-84

PubMed Abstract | Publisher Full Text

50. Bahuaud M, Beaudouin-Bazire C, Husson M, et al:: Immunogenicity and persistence of a prime-boost re-vaccination strategy for pneumococcal vaccines in patients with rheumatoid arthritis. Hum Vaccin Immunother. 2018; 14(6): 1464-70.

PubMed Abstract | Publisher Full Text | Free Full Text

51. Schuchat $\mathrm{A}:$ Pneumococcal prevention gets older and wiser. JAMA Intern Med. 2015; 175(12): 1897-8.

PubMed Abstract | Publisher Full Text | Free Full Text

52. Hochman M, Cohen PA: Reconsidering guidelines on the use of pneumococcal vaccines in adults 65 years or older. JAMA Intern Med. 2015; 175(12): 1895-6. PubMed Abstract | Publisher Full Text

53. $\mathrm{F}$ van der Linden M, Whitney CG: Herd protection or herding cats? Thorax 2019; 74(5): 425-6.

PubMed Abstract | Publisher Full Text | F1000 Recommendation

54. F Weinberger DM, Shapiro ED: Prevention of pneumococcal infections in adults using conjugate vaccines: no easy answers. Clin Infect Dis. 2019; 69(1): $50-1$.

PubMed Abstract | Publisher Full Text | Free Full Text | F1000 Recommendation

55. Prato R, Fortunato F, Martinelli D: Pneumococcal pneumonia prevention among adults: is the herd effect of pneumococcal conjugate vaccination in children as good a way as the active immunization of the elderly? Curr Med Res Opin. 2015; 32(3): 543-5.

PubMed Abstract | Publisher Full Text

56. F van der Linden M, Imöhl M, Perniciaro S: Limited indirect effects of an infant pneumococcal vaccination program in an aging population. PLOS One. 2019; 14(8): e0220453.

PubMed Abstract | Publisher Full Text | Free Full Text | F1000 Recommendation

57. F Albrich WC, Rassouli F, Waldeck F, et al:: Influence of older age and other risk factors on pneumonia hospitalization in Switzerland in the pneumococcal vaccine era. Front Med (Lausanne). 2019; 6: 286

PubMed Abstract | Publisher Full Text | Free Full Text | F1000 Recommendation

58. Menéndez R, España PP, Pérez-Trallero E, et al:: The burden of PCV13 serotypes in hospitalized pneumococcal pneumonia in Spain using a novel urinary antigen detection test. CAPA study. Vaccine. 2017; 35(39): 5264-70. PubMed Abstract | Publisher Full Text

59. Ceccato A, Torres A, Cilloniz C, et al:: Invasive disease vs urinary antigenconfirmed pneumococcal community-acquired pneumonia. Chest. 2017; 151(6): 1311-9.

PubMed Abstract | Publisher Full Text

60. Papadatou I, Spoulou V, Papasian CJ: Pneumococcal vaccination in high-risk 
individuals: are we doing it right? Clin Vaccine Immunol. 2016; 23(5): 388-95. PubMed Abstract | Publisher Full Text | Free Full Text

61. Falkenhorst G, Remschmidt C, Harder T, et al:: Effectiveness of the 23-valent pneumococcal polysaccharide vaccine (PPV23) against pneumococcal disease in the elderly: systematic review and meta-analysis. PLoS One. 2017; 12(1): e0169368.

PubMed Abstract | Publisher Full Text | Free Full Text

62. Djennad A, Ramsay ME, Pebody R, et al.: Effectiveness of 23-valen polysaccharide pneumococcal vaccine and changes in invasive pneumococcal disease incidence from 2000 to 2017 in those aged 65 and ove in England and Wales. EClinicalMedicine. 2019; 6: 42-50.

PubMed Abstract | Publisher Full Text | Free Full Text

63. Kim JH, Chun BC, Song JY, et al.: Direct effectiveness of pneumococcal polysaccharide vaccine against invasive pneumococcal disease and nonbacteremic pneumococcal pneumonia in elderly population in the era of pneumococcal conjugate vaccine: a case-control study. Vaccine. 2019; 37(21): 2797-804.

PubMed Abstract | Publisher Full Text

64. F Park SB, Kim HJ, Cheong HJ: Environmental factors which can affect the burden of pneumococcal disease and the immune response to pneumococcal vaccines: the need for more precisely delineated vaccine recommendations. Expert Rev Vaccines. 2019; 18(6): 587-96. PubMed Abstract | Publisher Full Text | F1000 Recommendation

65. Imai K, Petigara T, Kohn MA, et al.: Risk of pneumococcal diseases in adults with underlying medical conditions: a retrospective, cohort study using two Japanese healthcare databases. BMJ Open. 2018; 8(3): e018553. PubMed Abstract | Publisher Full Text | Free Full Text

66. F Pelton SI, Bornheimer R, Doroff R, et al:: Decline in Pneumococcal disease attenuated in older adults and those with comorbidities following universal childhood PCV13 immunization. Clin Infect Dis. 2019; 68(11): 1831-8. PubMed Abstract | Publisher Full Text | Free Full Text | F1000 Recommendation

67. F Weinberger DM, Shapiro ED: Pneumococcal vaccines for adults: what's next? Clin Infect Dis. 2019; pii: ciz743. PubMed Abstract | Publisher Full Text | F1000 Recommendation

68. F Goettler D, Streng A, Kemmling D, et al:: Increase in Streptococcus pneumoniae serotype 3 associated parapneumonic pleural effusion/empyem after the introduction of PCV13 in Germany. Vaccine. 2020; 38(3): 570-7. PubMed Abstract | Publisher Full Text | F1000 Recommendation

69. Centers for Disease Control and Prevention (CDC): Global Pneumococcal Disease and Vaccine. Accessed 23 Jan 2020. Reference Source

70. Wahl B, O'Brien KL, Greenbaum A, et al: Burden of Streptococcus pneumoniae and Haemophilus influenzae type $b$ disease in children in the era of conjugate vaccines: Global, regional, and national estimates for 2000-15. Lancet Glob Health. 2018; 6(7): e744-e757.

PubMed Abstract | Publisher Full Text | Free Full Text

71. Serum Institute of India: New pneumococcal vaccine from Serum Institute of India achieves WHO prequalification. Accessed 9 Jan 2020 Reference Source

72. Pfizer Inc: Pfizer announces serotypes included in 20-valent pneumococcal conjugate vaccine candidate being investigated for the prevention of invasive disease and pneumonia in adults aged 18 years and older. Accessed 21 Jan
2020

Reference Source

73. Thompson A, Lamberth E, Severs J, et al: Phase 1 trial of a 20-valent pneumococcal conjugate vaccine in healthy adults. Vaccine. 2019; 37(42): 6201-7.

Publisher Full Text

74. Watson, W, Hurley D, et al:: Safety, tolerability, and immunogenicity of a 20-valent pneumococcal conjugate vaccine in adults 60-64 years of age. Oral presentation 00087 at the 29th European Congress of Clinical Microbiology \& Infectious Diseases. Presented on Saturday 14 April 2019 Reference Source

75. F Greenberg D, Hoover PA, Vesikari T, et al:: Safety and immunogenicity of 15valent pneumococcal conjugate vaccine (PCV15) in healthy infants. Vaccine. 2018; 36(45): 6883-91.

Publisher Full Text | F1000 Recommendation

76. F Stacey HL, Rosen J, Peterson JT, et al:: Safety and immunogenicity of 15-valent pneumococcal conjugate vaccine (PCV-15) compared to PCV-13 in healthy older adults. Hum Vaccin Immunother. 2019; 15(3): 530-9. PubMed Abstract | Publisher Full Text | Free Full Text | F1000 Recommendation

77. F Peterson JT, Stacey HL, MacNair JE, et al.: Safety and immunogenicity of 15-valent pneumococcal conjugate vaccine compared to 13-valent pneumococcal conjugate vaccine in adults $\geq 65$ years of age previously vaccinated with 23 -valent pneumococcal polysaccharide vaccine. Hum Vaccin Immunother. 2019; 15(3): 540-8.

PubMed Abstract | Publisher Full Text | Free Full Text | F1000 Recommendation

78. Lee C, Choi SK, Kim RK, et al.: Development of a new 15-valent pneumococcal conjugate vaccine (PCV15) and evaluation of its immunogenicity. Biologicals. 2019; 61: 32-7.

PubMed Abstract | Publisher Full Text

79. F Converso TR, Assoni L, André GO, et al:: The long search for a serotype independent pneumococcal vaccine. Expert Rev Vaccines. 2020; 19(1): 57-70. PubMed Abstract | Publisher Full Text | F1000 Recommendation

80. Feldman C, Anderson R: Review: current and new generation pneumococcal vaccines. $J$ Infect. 2014; 69(4): 309-25 PubMed Abstract | Publisher Full Tex

81. F Keech CA, Morrison R, Anderson P, et al:: A Phase 1 Randomized, Placebocontrolled, observer-blinded trial to evaluate the safety and immunogenicity of inactivated Streptococcus pneumoniae whole-cell vaccine in adults. Pediatr Infect Dis J. 2020: 39(4): 345-351.

PubMed Abstract | Publisher Full Text | F1000 Recommendation

82. F Hammitt LL, Campbell JC, Borys D, et al.: Efficacy, safety and mmunogenicity of a pneumococcal protein-based vaccine co-administered with 13-valent pneumococcal conjugate vaccine against acute otitis media in young children: a phase Ilb randomized study. Vaccine. 2019; 37(51): 7482-92. PubMed Abstract | Publisher Full Text | F1000 Recommendation

83. F Odutola $\mathrm{A}$, Ota MOC, Antonio $\mathrm{M}$, et al: Immunogenicity of pneumococcal conjugate vaccine formulations containing pneumococcal proteins, and immunogenicity and reactogenicity of co-administered routine vaccines - a phase II, randomised, observer-blind study in Gambian infants. Vaccine. 2019 37(19): 2586-99.

PubMed Abstract | Publisher Full Text | F1000 Recommendation 


\section{Open Peer Review}

\section{Current Peer Review Status:}

\section{Editorial Note on the Review Process}

Faculty Reviews are review articles written by the prestigious Members of Faculty Opinions. The articles are commissioned and peer reviewed before publication to ensure that the final, published version is comprehensive and accessible. The reviewers who approved the final version are listed with their names and affiliations.

\section{The reviewers who approved this article are:}

\section{Version 1}

\section{Carlos Luna}

Department of Medicine, Pulmonary Diseases Division, Hospital de Clínicas, Universidad de Buenos Aires, Buenos Aires, Argentina

Competing Interests: No competing interests were disclosed.

\section{Cheng-Hsun Chiu}

Molecular Infectious Disease Research Center, Division of Pediatric Infectious Diseases, Chang Gung Memorial Hospital, Chang Gung University College of Medicine, Taoyuan, Taiwan

Competing Interests: No competing interests were disclosed.

The benefits of publishing with F1000Research:

- Your article is published within days, with no editorial bias

- You can publish traditional articles, null/negative results, case reports, data notes and more

- The peer review process is transparent and collaborative

- Your article is indexed in PubMed after passing peer review

- Dedicated customer support at every stage

For pre-submission enquiries, contact research@f1000.com

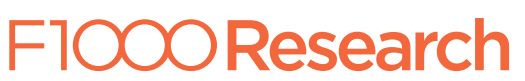

